\title{
Proces kształtowania celów polityki energetyczno-klimatycznej Unii Europejskiej do 2030 roku. Konsekwencje dla Polski
}

\section{Wprowadzenie}

Polityka energetyczno-klimatyczna Unii Europejskiej zmierza do stopniowego odchodzenia od paliw kopalnych w procesie wytwarzania energii elektrycznej i ciepła. Ma to doprowadzić do całkowitego wyeliminowania węgla i budowania gospodarki nisko i zero emisyjnej. Jest prawdopodobne, że kosztowny proces transformacji energetycznej nieco wyhamuje, w kontekście możliwego spowolnienia gospodarczego związanego z pandemią SARS-CoV-2, ale nie możemy się jednak spodziewać odwrócenia trendu. Wszystko wskazuje na to, że energetyka oparta na węglu, a szerzej udział węgla w generowaniu energii, będzie redukowana docelowo do zera.

Komisja Europejska pod przywództwem Ursuli von der Leyen, jako jeden ze swoich priorytetów wskazuje walkę ze zmianami klimatu i skutkami, jakie te zmiany wywołują w UE i jej najbliższym otoczeniu. Frans Timmermans został powołany na stanowisko wiceprzewodniczącego wykonawczego z zadaniem stymulowania i koordynowania polityki klimatycznej Unii Europejskiej w zakresie m.in. wdrażania Europejskiego Zielonego Ładu, zwiększania poziomu redukcji emisji, rozszerzania unijnego systemu handlu emisjami i koordynacji nad funduszem sprawiedliwej transformacji. Niniejszy artykuł przedstawia najważniejsze elementy tzw. pakietów energetyczno-klimatycznych Unii Europejskiej, ścieżki dochodzenia do wspólnotowych celów w zakresie energii w perspektywie do roku 2020 i do roku 2030, a także kierunki rozwoju polityki energetyczno-klimatycznej UE w horyzoncie roku 2050. Artykuł opisuje jej wpływ na polski sektor elektroenergetyczny a także zawiera wnioski i rekomendacje na przyszłość. 


\section{Pierwszy pakiet energetyczno-klimatyczny}

W latach osiemdziesiątych minionego wieku dyskusja na temat zmian klimatu wyszła poza wąski krąg klimatologów, specjalistów do spraw ochrony środowiska czy analityków globalnych trendów pogodowych i na trwałe zagościła w publicznej debacie. W 1988 r. Organizacja Narodów Zjednoczonych i Światowa Organizacja Meteorologiczna powołały do życia Międzynarodowy Zespół ds. Zmian Klimatu ${ }^{1}$ (dalej IPCC), najbardziej renomowaną organizację, która zajmuje się opisywaniem zmian klimatu, ich przyczyn i konsekwencji. Pierwszy raport przygotowany i opublikowany przez IPCC w 1990 r. dał asumpt do przyjęcia w Rio de Janeiro w 1992 r. Ramowej Konwencji Narodów Zjednoczonych ws. Zmian Klimatu. Unia Europejska włączyła się w ogólnoświatowe działania zmierzające do zahamowania zmian klimatu.

Jednym z najważniejszych przejawów aktywności UE w tym obszarze był przyjęty w 2008 r. zbiór wielosektorowych regulacji prawnych zwany pierwszym unijnym pakietem energetyczno-klimatycznym (tzw. pakiet 3x20 lub 20-20-20). Definiował on cele, jakie Wspólnota zobowiązuje się osiągnąć do roku 2020. Do najważniejszych zaliczyć można:

1) ograniczenie emisji gazów cieplarnianych o $20 \%$;

2) wzrost udziału energii z OZE w końcowym zużyciu energii o 20\%;

3) podniesienie efektywności energetycznej o $20 \%$.

W skład pakietu wchodził szereg aktów prawnych, które wytyczały ścieżki dojścia do wyznaczonych celów zarówno na poziomie wspólnotowym, jak i krajowym. Określały także zobowiązania instytucji unijnych i państw członkowskich. Do aktów prawnych wchodzących w skład pakietu należy zaliczyć:

1) Dyrektywę Parlamentu Europejskiego i Rady 2009/29/WE² (tzw. Dyrektywa EU ETS), która modyfikowała system handlu przydzielonymi poziomami emisji gazów cieplarnianych wprowadzony w październiku $2003 \mathrm{r}$. dyrektywą 2003/87/WE³ . Głównym celem wprowadzenia systemu handlu prawami do emisji gazów cieplarnianych było ograniczenie emisji poprzez wprowadzenie quasi rynkowych zasad. System ETS obejmował m.in.: elektrownie, duże instalacje przemysłowe i transport lotniczy, co w sumie odpowiadało za ok. $45 \%$ emisji UE. Limity emisji przyznawane i rozliczane są na poziomie przedsiębiorstw, co oznacza, że za emisje pewnej ilości gazów

Intergovermental Panel on Climate Change IPCC.

2 Dyrektywa Parlamentu Europejskiego i Rady 2009/29/WE, z dnia 23 kwietnia 2009 r. zmieniająca dyrektywę 2003/87/WE w celu usprawnienia i rozszerzenia wspólnotowego systemu handlu uprawnieniami do emisji gazów cieplarnianych.

3 Dyrektywa Parlamentu Europejskiego i Rady 2003/87/WE, z dnia 13 października 2003 r., ustanawiająca system handlu przydziałami emisji gazów cieplarnianych we Wspólnocie oraz zmieniająca dyrektywę Rady 96/61/WE. 
cieplarnianych przedsiębiorstwo musi umorzyć odpowiednią ilość przyznanych uprawnień. Dyrektywa miała przysłużyć się do osiągnięcia pierwszego z głównych celów pakietu tj. redukcji emisji gazów cieplarnianych.

2) Decyzję Parlamentu Europejskiego i Rady 2009/406/WE (tzw. Decyzja Non-ETS), która dotyczyła sektorów nie objętych systemem ETS, ale wytwarzających w sumie ok. 55\% wszystkich emisji. Do tych sektorów należy m.in.: mieszkalnictwo, rolnictwo, gospodarka odpadami, transport, handel. Non-ETS (w przeciwieństwie do UE ETS) dotyczy emisji krajowych, dlatego obowiązki sprawozdawczości spoczywają na administracji rządowej. Decyzja miała przysłużyć się do osiągnięcia pierwszego z głównych celów pakietu, tj. redukcji emisji gazów cieplarnianych. Wysiłki redukcyjne w ramach sektora Non-ETS Unia Europejska oparła na zasadzie solidarności, co oznaczało, że państwa o stosunkowo wysokim PKB powinny osiągnąć wyższe poziomy redukcji niż państwa o stosunkowo niskim PKB. Ramy redukcyjne zostały określone pomiędzy -20 a $+20 \%$ i określone dla każdego z państw członkowskich w załączniku II do Decyzji. Zgodnie z jego postanowieniami Polska mogła zwiększyć poziom emisji gazów cieplarnianych o 14\% względem roku bazowego 2005.

3) Dyrektywę Parlamentu Europejskiego i Rady 2009/31/WE ${ }^{5}$ w sprawie składowania dwutlenku węgla (tzw. Dyrektywa CCS - Carbon Capture and Storage). Polska z ponad rocznym opóźnieniem (względem unijnych wymogów) implementowała zapisy dyrektywy we wrześniu 2013 r. ${ }^{6}$. Ustawa odnosiła się jedynie do projektów demonstracyjnych wychwytu i składowania dwutlenku węgla realizowanych w celu potwierdzenia możliwości wykorzystywania tej technologii na skalę przemysłową. Ustawa wprowadziła istotny zapis o konieczności przeprowadzenia oceny gotowości instalacji do wychwytywania dwutlenku węgla, dostępności podziemnych składowisk a także technicznych i ekonomicznych możliwości wykonania sieci transportowych dwutlenku węgla ${ }^{7} \mathrm{w}$ procedurze uzyskania oceny oddziaływania na środowisko. Dyrektywa miała przysłużyć się do osiągnięcia pierwszego z głównych celów pakietu, tj. redukcji emisji gazów cieplarnianych.

Decyzja Parlamentu Europejskiego i Rady nr 2009/406/WE z dnia 23 kwietnia 2009 r., w sprawie wysiłków podjętych przez państwa członkowskie, zmierzających do zmniejszenia emisji gazów cieplarnianych w celu realizacji do roku 2020 zobowiązań Wspólnoty dotyczących redukcji emisji gazów cieplarnianych.

5 Dyrektywa Parlamentu Europejskiego i Rady 2009/31/WE, z dnia 23 kwietnia 2009 r., w sprawie geologicznego składowania dwutlenku węgla oraz zmieniająca dyrektywę Rady 85/337/ EWG, Euratom, dyrektywy Parlamentu Europejskiego i Rady 2000/60/WE, 2001/80/WE, 2004/35/WE, 2006/12/WE, 2008/1/WE i rozporządzenie (WE) nr 1013/2006.

6 Ustawa z dnia 27 września 2013 r., o zmianie ustawy Prawo geologiczne i górnicze oraz niektórych innych ustaw, Dz. U. 2013 poz. 1238.

Art. 9 pkt 2 i 4, ustawa z dnia 27 września 2013 r., o zmianie ustawy Prawo geologiczne. 


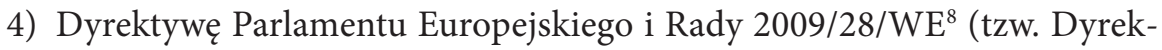
tywa OZE), która wprowadzała cele dla każdego z państw członkowskich wzrostu udziału odnawialnych źródeł energii w końcowym zużyciu energii brutto w 2020 r. ${ }^{9}$. Cele krajowe wpisywały się w cel wspólnotowy osiągnięcia w 2020 r. 20\% udziału odnawialnych źródeł energii w końcowym zużyciu energii brutto. Zgodnie z załącznikiem I do dyrektywy Parlamentu Europejskiego i Rady Unii Europejskiej 2009/28/WE ${ }^{10}$ Polska została zobowiązana, aby do roku 2020 wytwarzać co najmniej 15\% energii finalnej ze źródeł odnawialnych. Był to wzrost o 7,8\% w porównaniu z rokiem referencyjnym 2005, w którym udział OZE w finalnym zużyciu energii wynosił 7,2\%.

Przyjęte akty prawne w ramach pakietu energetyczno-klimatycznego nie odnosiły się bezpośrednio do efektywności energetycznej. Tę kwestię regulowała przyjęta w 2006 r. Dyrektywa Parlamentu Europejskiego i Rady 2006/32/WE ${ }^{11}$.

\section{Ścieżka dojścia do drugiego pakietu energetyczno-klimatycznego}

Przyjęty w 2008 r. pakiet energetyczno-klimatyczny wyznaczał cele, których perspektywa realizacji określona była na rok 2020. Na początku dekady Komisja rozpoczęła prace nad kolejnym pakietem, który określiłby cele w perspektywie 2020-2030. W marcu 2011 r. Komisja przyjęła Plan działania prowadzacy do przejścia na konkurencyjna gospodarkę niskoemisyjna do 2050 roku ${ }^{12}$. Po przeanalizowaniu czynników kształtujących ceny paliw kopalnych, a także różne wskaźniki innowacji, Komisja opracowała zakładane poziomy redukcji dla poszczególnych sektorów gospodarki (zobacz tabelę $\mathrm{nr}$ 1).

8 Dyrektywa Parlamentu Europejskiego i Rady 2009/28/WE, z dnia 23 kwietnia 2009 r., w sprawie promowania stosowania energii ze źródeł odnawialnych zmieniająca i w następstwie uchylająca dyrektywy 2001/77/WE oraz 2003/30/WE.

9 Metodę obliczania udziału energii z OZE w końcowym zużyciu energii opisuje art. 5. Dyrektywy OZE.

10 Dyrektywa Parlamentu Europejskiego i Rady 2009/28/WE, z dnia 23 kwietnia 2009 r., w sprawie promowania stosowania energii ze źródeł odnawialnych zmieniająca i w następstwie uchylająca dyrektywy 2001/77/WE oraz 2003/30/WE.

11 Dyrektywa Parlamentu Europejskiego i Rady 2006/32/WE, z dnia 5 kwietnia 2006 r., w sprawie efektywności końcowego wykorzystania energii i usług energetycznych oraz uchylająca dyrektywę Rady 93/76/EWG.

12 Komunikat Komisji do Parlamentu Europejskiego, Rady, Europejskiego Komitetu Ekonomiczno-Społecznego i Komitetu Regionów, Plan działania prowadzący do przejścia na konkurencyjną gospodarkę niskoemisyjną do 2050 r., Bruksela 9.03.2011, KOM(2011) 112. 
Tabela 1. Zakładane redukcje poziomów emisji $\mathrm{CO}_{2}$ w poszczególnych sektorach gospodarki do roku 2050.

\begin{tabular}{|l|c|c|c|}
\hline \multicolumn{1}{|c|}{$\begin{array}{c}\text { Poziom redukcji gazów } \\
\text { cieplarnianych względem roku } \\
\text { bazowego 1990 }\end{array}$} & $\begin{array}{c}\text { Poziom redukcji } \\
\text { do roku 2005 }\end{array}$ & $\begin{array}{c}\text { Zakładany } \\
\text { poziom redukcji } \\
\text { do roku 2030 }\end{array}$ & $\begin{array}{c}\text { Zakładany } \\
\text { poziom redukcji } \\
\text { do roku 2050 }\end{array}$ \\
\hline Energetyka & $-7 \%$ & Od $-54 \%$ do $-68 \%$ & Od $-93 \%$ do $-99 \%$ \\
\hline Przemysł & $-20 \%$ & Od $-34 \%$ do $-44 \%$ & Od $-83 \%$ do $-87 \%$ \\
\hline $\begin{array}{l}\text { Transport (łącznie z lotnictwem, ale } \\
\mathbf{z} \text { wyłączeniem transportu morskiego) }\end{array}$ & $+30 \%$ & Od $+20 \%$ do $-9 \%$ & Od $-54 \%$ do $-67 \%$ \\
\hline Mieszkalnictwo i usługi & $-12 \%$ & Od $-37 \%$ do $-53 \%$ & Od $-88 \%$ do $-91 \%$ \\
\hline Rolnictwo & $-20 \%$ & Od $-36 \%$ do $-37 \%$ & Od $-42 \%$ do $-49 \%$ \\
\hline
\end{tabular}

Źródło: opracowanie własne na podstawie Komunikatu Komisji do Parlamentu Europejskiego, Rady, Europejskiego Komitetu Ekonomiczno-Społecznego i Komitetu Regionów, Plan działania prowadzący do przejścia na konkurencyjną gospodarkę niskoemisyjną do 2050 r., Bruksela 9.03.2011, $\mathrm{KOM}(2011)$ 112, s. 7.

Z danych ujętych w tabeli 1 wynika, że Komisja Europejska zakładała proporcjonalnie największą redukcję emisji $\mathrm{CO}_{2} \mathrm{w}$ sektorze energetycznym nawet do 99\% w 2050 r. (względem roku bazowego 1990). Tak duże redukcje miały zostać osiągnięte poprzez wzrost technologii niskoemisyjnych w koszyku energetycznym do ok. 60\% w 2020 r. a także realizacji celu w zakresie udziału odnawialnych źródeł energii do 75-80\% w 2020 r. i 100\% w 2050 r. ${ }^{13}$.

W grudniu 2011 r. Komisja Europejska przyjęła Plan działania w zakresie energii do roku $2050^{14}$. Plan stanowił rozwinięcie przyjętego kilka miesięcy wcześniej Planu na rzecz gospodarki niskoemisyjnej, a także pogłębienie celów polityki energetyczno-klimatycznej przyjętych w ramach pakietu energetyczno-klimatycznego w 2008 r. Jednym z głównych elementów tego opracowania było określenie wyzwań związanych z przyjętym przez UE celu w zakresie dekarbonizacji przy jednoczesnym zapewnieniu bezpieczeństwa dostaw i konkurencyjności zarówno w zakresie sposobów wytwarzania energii, jak i całej unijnej gospodarki. Komisja skoncentrowała się na sektorze energetycznym z uwagi na relatywnie wysoki poziom emisyjności w porównaniu do pozostałych sektorów. Komisja Europejska wskazała kilka obszarów, w których należało podjąć działania w celu osiągnięcia zakładanych celów. Do najbardziej istotnych (także z punktu widzenia transformacji polskiego sektora energetycznego) należały:

13 Komunikat Komisji, Plan działania prowadzący do przejścia na konkurencyjna gospodarkę niskoemisyjna do 2050 r., Bruksela 9.03.2011, $\operatorname{KOM}(2011)$ 112, s. 7.

14 Komunikat Komisji do Parlamentu Europejskiego, Rady, Europejskiego Komitetu Ekonomiczno-Społecznego i Komitetu Regionów, Plan działania w zakresie energii do roku 2050, Bruksela 15.12.2011, KOM(2011) 885 . 
1) dekarbonizacja systemu energetycznego;

2) zwiększenie udziału energii z odnawialnych źródeł w finalnym zużyciu energii;

3) tworzenie jednolitego rynku energii poprzez tworzenie infrastruktury technicznej, ale także likwidowanie nieprawidłowości regulacyjnych i strukturalnych lokalnych rynków;

4) rozwój technologii CCS;

5) rozwój nowej infrastruktury energetycznej i zdolności magazynowania energii.

Komisja Europejska w Planie działania w zakresie energii do roku 2050 opracowała scenariusze dekarbonizacji sektora energetycznego w perspektywie niemal czterdziestu lat. Powoduje to występowanie sporej ilości czynników, których wpływu na transformację sektora energetycznego nie jesteśmy w stanie przewidzieć. Należą do nich przede wszystkim dostępność zasobów naturalnych, globalny popyt na nie i ceny nośników energii, tempo wzrostu gospodarczego, skuteczność wysiłków wspólnoty międzynarodowej odnośnie zapobiegania zmianom klimatu oraz tempo postępu technologicznego w zakresie wytwarzania energii.

W lutym 2012 r. polski rząd przyjął stanowisko odnośnie Planu działań w zakresie energii do roku 2050. Postulował w nim zachowanie równowagi między trzema filarami polityki energetycznej Unii Europejskiej, to jest: zrównoważonym rozwojem, bezpieczeństwem energetycznym oraz konkurencyjnością gospodarki. Zarysował w nim główne rozbieżności między wizją Komisji Europejskiej a stanowiskiem Polski. Do najważniejszych z nich, w odniesieniu do sektora energetycznego, można zaliczyć:

1) Komisja zmierza do marginalizacji paliw kopalnych w procesie pozyskania energii, nie biorąc pod uwagę technologii (poza CCS - której skuteczność nie została komercyjnie potwierdzona) tzw. czystego wykorzystania węgla. Wybór stosowanych technologii wytwarzania energii powinien opierać się na kryterium efektywności ekonomicznej;

2) preferowanie odnawialnych źródeł energii (głównie energetyki wiatrowej i fotowoltaiki) przy jednoczesnym bagatelizowaniu relatywnie niskiego potencjału Polski (w porównaniu do niektórych państw unijnych) może doprowadzić do sytuacji, w której Polska będzie zmuszona do importu energii elektrycznej;

3) proces dekarbonizacji wpłynie na wzrost cen i obniżenie konkurencyjności unijnej gospodarki.

Konkluzją stanowiska było stwierdzenie, że Rząd Polski „nie widzi podstaw do redukcji emisji do roku 2020, jak również do określenia nowych celów redukcyjnych na lata po $2020 \mathrm{r} .{ }^{\prime 15}$.

15 Stanowisko Rządu RP wobec komunikatu, „Plan działania w zakresie energii do roku 2050”, s. 6. 
W marcu 2013 r. Komisja Europejska opublikowała tzw. Zieloną Księgę, rozpoczynając tym samym proces konsultacji ram polityki w zakresie klimatu i energii do roku $2030^{16}$. Rząd RP w czerwcu 2013 r. wydał stanowisko w odniesieniu do planów Komisji Europejskiej ujętych z Zielonej Księdze. Główne linie rozbieżności można ująć w pięciu najważniejszych punktach:

1) obecny system handlu emisjami (EU ETS) działa efektywnie i nie wymaga korekty. Planowane przez Komisję administracyjne zmiany podważają jego rynkowy charakter i zwiększą niepewność inwestycyjną (s. 4-5 Stanowiska Rządu RP);

2) wsparcie finansowe dla odnawialnych źródeł energii, które osiągają dojrzałość technologiczną i ekonomiczną, powinno być sukcesywnie wycofywane w ramach utrzymania konkurencyjności energii wytwarzanej z różnych źródeł (s. 5 Stanowiska Rządu RP). Systemy wspierające OZE powinny pozostać w gestii państw członkowskich dając im tym samym możliwość rozwoju tych technologii, które mają największy potencjał biorąc pod uwagę geograficzne właściwości danego kraju (s. 8 Stanowiska Rządu RP);

3) wyznaczanie nowych celów unijnej polityki energetyczno-klimatycznej powinno być uzależnione od wyniku międzynarodowych negocjacji odnośnie do redukcji emisji gazów cieplarnianych, a także powiązane z realnymi działaniami głównych emiterów (s. 6-7 Stanowiska Rządu RP);

4) nierynkowe utrzymywanie wysokich cen energii z paliw kopalnych lub cen praw do emisji nie powinno być mechanizmem transformacji niskoemisyjnej. W innym przypadku zostanie obniżona konkurencyjność unijnej gospodarki wobec takich globalnych konkurentów jak Stany Zjednoczone czy Japonia, gdzie ceny energii są niższe (s. 9 Stanowiska Rządu RP);

5) cele redukcji powinny być dostosowane m.in. do zasobności poszczególnych państw członkowskich, warunków geograficzno-klimatycznych, struktury sektora wytwarzania energii, dostępności zasobów odnawialnych (s. 10 Stanowiska Rządu RP).

Mimo sceptycznego stanowiska Polskiego Rządu wobec lansowanych przez Komisję Europejską kierunków zmian polityki energetyczno-klimatycznej do roku 2030, prace nad wyznaczeniem kolejnych celów były kontynuowane. W lutym 2014 r. Komisja Europejska przyjęła ramy polityki energetyczno-klimatycznej na okres $2020-2030^{17}$. Główne cele zostały określone w sposób następujący:

1) redukcja poziomów emisji gazów cieplarnianych o $40 \% \mathrm{w}$ porównaniu z rokiem bazowym 1990. Poziom redukcji został podzielony na sektor objęty

16 Zielona Księga. Ramy polityki w zakresie klimatu i energii do roku 2030. Bruksela 27.03.2013. $\operatorname{COM}(2013) 169$ final.

17 Komunikat Komisji do Parlamentu Europejskiego, Rady, Europejskiego Komitetu Ekonomiczno-Społecznego i Komitetu Regionów, Ramy polityczne na okres 2020-2030 dotyczące klimatu i energii, COM(2014)15final. 
unijnym systemem handlu emisjami (UE ETS), w którym zakładana redukcja powinna wynieść $43 \%$ w porównaniu z rokiem 2005 i sektor nie objęty systemem handlu emisjami (UE Non-ETS), w którym zakładana redukcja powinna wynieść $30 \% \mathrm{w}$ porównaniu $\mathrm{z}$ rokiem 2005 . Cel redukcyjny jaki KE proponowała Polsce to $-7 \%$ poziomu emisji z roku 2005, co było sporym wyzwaniem, zważywszy na fakt, że w perspektywie do 2020 mogliśmy zwiększyć emisje w tym sektorze o $14 \%$;

2) wzrost udziału odnawialnych źródeł energii w finalnym bilansie zużycia do $27 \%$;

3) reforma systemu handlu emisjami poprzez utworzenie rynkowej rezerwy stabilizacyjnej na początku 4. etapu handlu emisjami w $2021 \mathrm{r}$.

Polski Rząd odniósł się do tych propozycji w swoim stanowisku z 6 III 2014 r., poddając krytyce główne unijne założenia. Dotyczyła ona m.in.:

1) zbyt dużych negatywnych społeczno-gospodarczych skutków wprowadzania ambitnych celów energetyczno-klimatycznych względem wpływu na zmiany klimatu w skali globalnej. Państwa Unii Europejskiej odpowiadają jedynie za $11 \%$ globalnych emisji. Unijne cele redukcyjne powinny mieć charakter warunkowy, uzależniający ich wdrożenie od działań innych dużych globalnych emiterów;

2) zasady neutralności technologicznej (technology neutral approach), którą Komisja powinna stosować. Dałaby ona państwom członkowskim swobodę w kreowaniu własnej drogi do gospodarki niskoemisyjnej bez promowania konkretnych technologii lub źródeł energii;

3) znacznego podniesienia celu redukcyjnego w sektorach nie objętych europejskim systemem handlu emisjami będzie powodowało znaczący wzrost obciążeń;

4) tempa procesu transformacji energetycznej, które powinno być rozłożone między państwa członkowskie bardziej sprawiedliwie, odzwierciedlając różnice m.in. w zasobności, warunkach geograficzno-klimatycznych, stopnia rozwoju, posiadanych surowców energetycznych itp.

\section{Drugi pakiet energetyczno-klimatyczny}

W listopadzie 2016 r. Komisja Europejska zaprezentowała pakiet energetyczno-klimatyczny pod nazwą Czysta energia dla wszystkich Europejczyków (Clean Energy for All Europeans Package), szerzej znany pod nazwą Pakiet Zimowy. Zawierał on rekomendację Komisji Europejskiej w zakresie polityki energetyczno-klimatycznej do roku 2030. Po ponad dwuletnich negocjacjach, w grudniu 2018 r., Parlament Europejski, Komisja i Rada Europejska ogłosiły zawarcie kompromisu w zakresie ostatnich dwóch komponentów Pakietu Zimowego. Do głównych postanowień należy zaliczyć: 
1) redukcję emisji o co najmniej $40 \%$ względem roku bazowego 1990. Redukcje zostały podzielone na podmioty objęte europejskim systemem handlu emisjami (UE ETS) i te spoza tego systemu (non-ETS). Temu pierwszemu przypisano redukcję o $43 \%$ względem roku 2005. Sektor non-ETS powinien wygenerować do $2030 \mathrm{r}$. redukcje na poziomie $30 \%$ względem roku 2005, z tym że każdemu z krajów przypisano minimalny poziom redukcji. Polska powinna osiągnąć redukcję na poziomie $-7 \%$. Komisja Europejska w ramach realizacji programu Europejskiego Zielonego Ładu planuje podnieść cel redukcyjny do 50 a nawet 55\%;

2) zwiększenie energii z OZE w finalnym zużyciu energii do co najmniej $32 \%$. Należy pamiętać, że jest to cel wspólnotowy. Polska określiła swój cel w przesłanym Komisji Europejskiej w grudniu 2019 r. Krajowym Planie na Rzecz Energii i Klimatu. Zgodnie z jego założeniami Polska zobowiązała się do osiągnięcia 21\% OZE w finalnym zużyciu energii do roku 2030 (łącznie elektroenergetyka, transport, ciepłownictwo oraz chłodnictwo) ${ }^{18}$. Możliwe jest osiągnięcie poziomu 23\% finalnego zużycia energii z OZE, ale pod warunkiem przyznania dodatkowych środków na sprawiedliwą transformację. Po roku 2023 planowany jest przegląd ścieżki dochodzenia do tego poziomu z możliwością jego podniesienia;

3) zwiększenie efektywności energetycznej do poziomu co najmniej 32,5\%;

4) kolejny etap tworzenia wspólnego, ogólnounijnego rynku energii elektrycznej ${ }^{19}$, jako jednego z filarów Unii Energetycznej. Aby powstał należy stworzyć techniczne możliwości synchronizacji systemów, czym zająć się mają powołane przez operatorów systemowych Regionalne Centra Operacyjne. Wysiłki unifikacyjne będę koordynowane przez Agencję ds. Współpracy Organów Regulacji Energetyki (ACER) ${ }^{20}$;

5) w zakresie bezpieczeństwa ${ }^{21}$ Unia Europejska dąży do osiągnięcia jednolitego poziomu gotowości państw członkowskich do reagowania w sytuacjach kryzysowych w sektorze elektroenergetycznym, między innymi

18 Krajowy plan na rzecz energii i klimatu na lata 2021-2030. Założenia i cele oraz polityki i działania, wersja $4.1 \mathrm{z}$ dnia 18.12.2019, s. 31 .

19 Chodzi o dwie regulacje: Rozporządzenie Parlamentu Europejskiego i Rady (UE) 2019/943, z dnia 5 czerwca 2019 r., w sprawie rynku wewnętrznego energii elektrycznej, Dz. Urz. UE, 14.6.2019 L 158/54; Dyrektywa Parlamentu Europejskiego i Rady (UE) 2019/944, z dnia 5 czerwca 2019 r., w sprawie wspólnych zasad rynku wewnętrznego energii elektrycznej oraz zmieniająca dyrektywę 2012/27/U E, Dz. Urz. UE z 14.6.2019, L 158/125.

Rozporządzenie Parlamentu Europejskiego i Rady (UE) 2019/942, z dnia 5 czerwca 2019 r., ustanawiające Agencję Unii Europejskiej ds. Współpracy Organów Regulacji Energetyki, Dz. Urz. UE z 14.06.2019, L 158/22.

21 Rozporządzenie Parlamentu Europejskiego i Rady (UE) 2019/941, z dnia 5 czerwca 2019 r., w sprawie gotowości na wypadek zagrożeń w sektorze energii elektrycznej i uchylające dyrektywę 2005/89/WE, Dz. Urz. UE z 14.06.2019, L 158. 
poprzez: wprowadzenie jednolitych zasad identyfikacji i ocen ryzyk, obowiązek opracowania planów na wypadek wystąpienia zagrożeń i powołania Grupy Koordynacyjnej ds. Energii Elektrycznej ${ }^{22}$.

Państwa zostały zobowiązane do stworzenia zintegrowanych krajowych planów w dziedzinie energii i klimatu na lata 2021-2030 strategii w zakresie energii i klimatu.

W grudniu 2019 r. Komisja Europejska przyjęła komunikat Europejski Zielony $\mathrm{Ład}^{24}$, który jest zbiorem niemal 50 działań w różnych sektorach zmierzających do ochrony klimatu. Jednym z głównych celów jest osiągnięcie neutralności klimatycznej do połowy XXI wieku. Symptomatyczny jest także zapis o redukcji emisji gazów cieplarnianych do poziomu 50-55\% (względem roku 1990). Będzie to oznaczać istotny wzrost cen praw do emisji:

1) redukcja 50\% (scenariusz GHG50) - 34 EUR w 2025 r. i 52 EUR w 2030 r.;

2) redukcja 55\% (scenariusz GHG55) - 41 EUR w 2025 r. i 76 EUR w 2030 r. ${ }^{25}$.

Pociągnie to radykalny wzrost obciążeń dla polskiego systemu elektroenergetycznego, w którym udział węgla zacznie spadać dopiero po wycofaniu mocy wytwórczych opartych na węglu brunatnym i uruchomieniu w ich miejsce energetyki atomowej, co ma nastąpić dopiero około roku 2035.

\section{Polityka energetyczno-klimatyczna Unii Europejskiej - konsekwencje dla Polski}

\section{Niski udział odnawialnych źródeł energii w finalnym zużyciu energii}

Jedną z kluczowych regulacji pakietu energetyczno-klimatycznego 20-20-20 było podniesienie udziału OZE w finalnym zużyciu energii w UE w 2020 r. do 20\%. Polsce wyznaczono cel krajowy na poziomie $15 \%$ udziału energii z odnawialnych źródeł energii w finalnym jej zużyciu. Już w maju 2016 r. Instytut Jagielloński, analizując zbyt powolny wzrost udziału OZE w finalnym zużyciu energii, sugerował, że Polska nie osiągnie zakładanych $15 \%$ do 2020 r. $^{26}$. Podobne wnioski znalazły się

22 M. Sobolewski, Pakiet „Czysta energia dla wszystkich Europejczyków” - nowa inicjatywa w dziedzinie unijnej polityki energetycznej, „Studia BAS” 2017, nr 3 (51), s. 124.

23 Ostateczne wersje miały zostać wysłane do KE do końca 2019 r. Polska wywiązała się z tego obowiązku.

24 Komunikat Komisji do Parlamentu Europejskiego, Rady Europejskiej, Rady, Komitetu Ekonomiczno-społecznego i Komitetu regionów, Europejski Zielony Ład, Bruksela, 11.12.2019, $\operatorname{COM}(2019) 640$ final.

25 R. Jeszke, M. Rosłaniec, M. Pyrka, I. Tobiasz, P. Mzyk, „Europejski Zielony Ład” a podniesienie ambicji klimatycznych UE do 2030 roku, „Polish Brief Energy” 2020, nr 1-2, s. 22.

26 Ch. Schnell, Wykonanie celu OZE 2020. Analiza stanu obecnego i prognoza, Warszawa 2016. 
w opublikowanym w listopadzie 2018 r. raporcie NIK odnośnie rozwoju odnawialnych źródeł energii ${ }^{27}$. Na początku 2019 r. media podały informację $e^{28}$, a rząd Polski w przesłanym do Komisji Europejskiej Krajowym planie na rzecz energii i klimatu na lata 2021-2030 (projekt) ${ }^{29}$ przyznał, że 15\% udział OZE w finalnym zużyciu nie zostanie osiągnięty w $2020 \mathrm{r}$. Plan zakłada osiągnięcie tego poziomu dopiero w roku 2022. Niewywiązanie się przez Polskę z unijnych zobowiązań może pociągnąć za sobą dwa negatywne scenariusze: wprowadzenie sankcji lub ewentualnie konieczność zakupu energii od innych państw członkowskich, które mają nadwyżkę produkcji z OZE. Interpretacja udziału OZE przez Brukselę dotyczy poziomów zużycia energii a nie jej wytworzenia. Najwyższa Izba Kontroli w raporcie z kontroli sektora OZE szacuje potencjalny koszt zakupu tej energii na 8 mld PLN ${ }^{30}$.

Zgodnie z przyjętymi w tzw. Pakiecie Zimowym regulacjami, udział OZE w finalnym zużyciu energii do 2030 r. powinien osiągnąć poziom 32\%. W projekcie rządowej strategii Polityka Energetyczna Polski do 2040 roku ${ }^{31}$ (dalej PEP2040) założone zostało zwiększenie udziału OZE w finalnym zużyciu energii w Polsce na poziomie $21 \%$ do 2030 roku. Podniesienie tego poziomu o dodatkowe $2 \%$, tj. do 23\%, zgodnie z założeniami PEP2040, będzie zależało od dotacji unijnych przyznanych Polsce w ramach sprawiedliwej transformacji. Krajowy plan na rzecz energii i klimatu na lata 2021-2030 określa następujące etapy osiągnięcia tego celu: rok 2022 ok. 15\%, rok 2025 ok. 17\%, rok 2027 ok. 19\% ${ }^{32}$. W sektorze elektroenergetycznym udział OZE będzie kształtował się na wyższych poziomach 32\% w 2030 r. i 40\% w 2040 r. Zwiększanie udziału odnawialnych źródeł energii pociąga za sobą sporo korzyści dla polskiego sektora elektro-energetycznego takich jak np. dywersyfikacja lokalnej infrastruktury wytwórczej, zerowa emisyjność czy ograniczenie importu, ewentualnie wydobycia paliw kopalnych. Należy postawić jednak pytanie, czy założenia PEP2040 odnośnie udziału OZE w finalnym zużyciu energii są realistyczne? W dekadzie 2010-2020 podnieśliśmy udział OZE w finalnym zużyciu energii tylko o 4,55\% z 9,25\% do 13,8\% i nie osiągnęliśmy zakładanych celów. W dekadzie 2020-2030 r. rząd zakłada zwiększenie dynamiki wzrostu blisko dwukrotnie, tj. o 8,0\% (z 13,8\% w roku 2020 do $21 \%$ w roku 2040), choć już wiadomo, że wyliczenia podane w PEP2040 są nieaktualne i ścieżka dojścia zostanie przesunięta o co najmniej dwa lata.

27 Informacja NIK o wynikach kontroli: Rozwój sektora odnawialnych źródeł energii, Nr ewid. 171/2017/P/17/020/KGP.

28 B. Oksińska, Porażka Polski w rozwoju OZE. Nie osiągniemy celu, https://www.rp.pl/ENERGIA-OZE/301139983-Porazka-Polski-w-rozwoju-OZE-Nie-osiagniemy-celu.html (10 VIII 2020).

29 Krajowy plan na rzecz energii i klimatu na lata 2021-2030. Założenia i cele oraz polityki i działania, PROJEKT - w. 3.1 z 04.01.2019, https://www.gov.pl/web/aktywa-panstwowe. Informacja NIK o wynikach kontroli: Rozwój sektora odnawialnych źródeł energii, s. 10.

31 Polityka Energetyczna Polski do 2040 roku, projekt wersja: 2.1, z dnia 08.11.2019, s. 52.

$32 \quad$ Krajowy plan na rzecz energii..., s. 18. 


\section{Wysokie ceny energii elektrycznej w Polsce i ich konsekwencje}

Długofalowym celem UE jest wprowadzenie gospodarki nisko lub zeroemisyjnej i osiągnięcie maksymalnego poziomu dekarbonizacji. Komisja Europejska planowała wprowadzenie w Pakiecie Zimowym zapisu, że jednostki emitujące powyżej $550 \mathrm{~g} \mathrm{CO}_{2} / \mathrm{KWh}$ nie będą mogły otrzymywać wsparcia ze środków publicznych, co oznaczałoby poważne konsekwencje dla polskiego sektora energetycznego, w którym blisko 80\% energii elektrycznej produkowane jest $\mathrm{z}$ węgla. Polsce udało się przeforsować stanowisko, w ramach którego instalacje emitujące powyżej $550 \mathrm{~g} \mathrm{CO}_{2} / \mathrm{KWh}$ będą mogły otrzymać wsparcie do lipca $2025 \mathrm{r}$. Dodatkowo wszystkie kontrakty na produkcję energii elektrycznej zawarte przed 31 XII 2019 r. nie będę musiał być dostosowane do nowych reguł. To oznacza przedłużenie pracy wysokoemisyjnych bloków węglowych.

Pakiet Zimowy wprowadził wyższe cele redukcji emisji gazów cieplarnianych. Pociągnie to za sobą reformę unijnego systemu handlu emisjami, a co za tym idzie wzrost cen na prawa do emisji $\mathrm{CO}_{2}$. To przełoży się na wzrost i tak relatywnie wysokich cen energii elektrycznej w Polsce w porównaniu $\mathrm{z}$ krajami regionu (zobacz wykres 1). W ujęciu średniorocznym cena energii elektrycznej w państwach naszego regionu rosła w 2018 roku w tempie 41-64 PLN za 1 MWh, czyli między 26 a $44 \%$ w porównaniu z rokiem $2017^{33}$. W tym samym okresie w Polsce ceny hurtowe energii elektrycznej wzrosły o 65 PLN za 1 MWh co oznaczało wzrost o $42 \%$ w porównaniu z poprzednim rokiem ${ }^{34}$. Wzrost cen, mimo że wysoki, wpisywał się w górne ramy trendu rynkowego w krajach naszego regionu.

Rok 2019 przyniósł pogłębienie różnic w cenach energii w regionie. W państwach ościennych odnotowano $12-15 \%$ spadki cen energii (to jest między 2428 PLN za $1 \mathrm{MWh}$ ), gdy w Polsce w tym samym okresie był wzrost cen o 3\% (to jest o 7 PLN/MWh) ${ }^{35}$. Wysokie ceny hurtowe energii elektrycznej w Polsce powodują zwiększony import energii. Zgodnie z danymi Polskich Sieci Elektroenergetycznych przez pierwszych pięć miesięcy 2020 r. import wzrósł o 39\% w porównaniu $\mathrm{z}$ analogicznym okresem 2019 r. i wynosił 8,4\% zużycia prądu. Najwięcej energii elektrycznej importowaliśmy ze Szwecji i Niemiec (zobacz wykres 2), czyli państw, w których OZE wytwarzają znaczący procent energii elektrycznej: Niemcy (34\%) i Szwecja (58\%), podczas gdy w Polsce było to $14,4 \%{ }^{36}$.

33 Polska Grupa Energetyczna, Raport Zintegrowany 2018, https://raportzintegrowany2018.gkpge.pl/pge-w-procesie-zmiany/otoczenie/otoczenie-rynkowe/ (20 VIII 2020).

34 Ibidem.

35 Ibidem.

36 B. Bieliszczuk, Rozwój odnawialnych źródeł energii - implikacje dla bezpieczeństwa i polityki zagranicznej Polski, „Biuletyn PISM”, nr 56 (1804), s. 1. 
Wykres 1. Porównanie średnich cen energii elektrycznej w Polsce i krajach regionu w 2018 roku (ceny w PLN/MWh, średni kurs EUR/PLN 4,30)

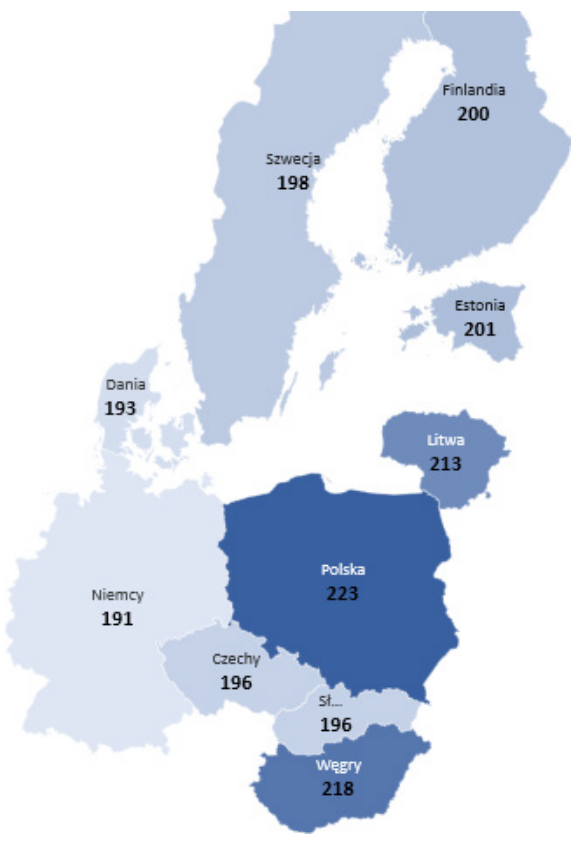

Źródło: opracowanie własne na podstawie: Polska Grupa Energetyczna, Raport Zintegrowany 2018.

Wykres 2. Geograficzna struktura importu energii elektrycznej w Polsce w okresie styczeń-maj 2020 r. (w GWh)

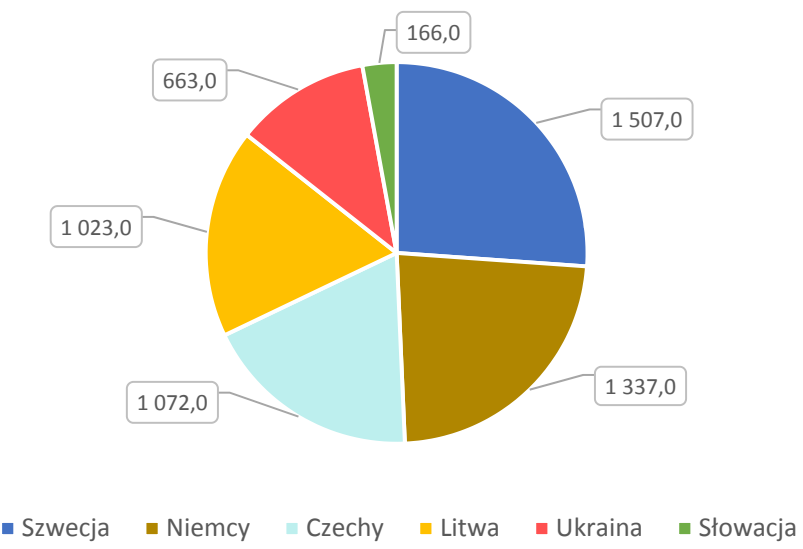

Źródło: opracowanie własne na podstawie: J. Żylińska, Nasz prąd jest drogi, więc importujemy, „Dziennik Gazeta Prawna”, 14 VII 2020, s. A8. 
Tworzony przez Unię Europejską wspólny rynek energii, rozdział producentów energii od dystrybutorów i właścicieli sieci przesyłowych, a także powiększenie przepustowości połączeń międzysystemowych będzie powodował zwiększenie importu energii elektrycznej do Polski. Pakiet Zimowy wprowadził konieczność udostępnienia 70\% technicznych możliwości przesyłowych połączeń międzysystemowych na potrzeby handlu transgranicznego ${ }^{37}$. Regulacja weszła w życie 1 I 2020 r. Rozporządzenie w sprawie rynku wewnętrznego przewiduje dwie możliwości: odroczenia wprowadzania zmian na 2 lata lub opracowanie tzw. Action Plan, który stopniowo do 2025 r. przygotuje system elektroenergetyczny na możliwość przeznaczenia 70\% mocy przesyłowych na handel transgraniczny.

\section{Wnioski i rekomendacje}

Analiza dokumentów unijnych różnej rangi i znaczenia (od tzw. zielonych ksiąg i komunikatów po decyzje i dyrektywy) wskazuje, że Unia Europejska, niezależnie od składu politycznego Parlamentu Europejskiego, Komisji czy Rady Europejskiej dąży do wprowadzenia ambitnych celów redukcji emisji gazów cieplarnianych, w tym przede wszystkim $\mathrm{CO}_{2}$, rozwoju odnawialnych źródeł energii i zwiększenia ich udziału w finalnym zużyciu energii elektrycznej. Polskie władze starają się w miarę możliwości co najmniej spowolnić ten proces. Determinacja unijnych instytucji i części państw członkowskich we wprowadzaniu Zielonego Ładu sugeruje, że wysiłki strony polskiej nie przyniosą spodziewanych efektów. Należy dokonać przeglądu polityki energetycznej, przyjąć długoletnią strategię odchodzenia od paliw kopalnych na drodze politycznego konsensusu i konsekwentnie ją realizować.

Coraz bardziej ambitne cele redukcji emisji $\mathrm{CO}_{2}$ będą wpływały negatywnie na cenę energii elektrycznej generowanej ze źródeł węglowych. Polski system elektroenergetyczny oparty jest na blokach węglowych. Z ogólnej liczby 90 bloków wchodzących w skład jednostek wytwórczych centralnie dysponowanych (JWCD), aż 70 przekroczyło zakładany czas eksploatacji ${ }^{38}$. Należy je zmodernizować, dostosować do dyrektywy BAT (Best Available Techniques) w celu poprawy ich elastyczności, aby mogły stanowić uzupełnienie i wsparcie dla OZE.

Pakiet Zimowy uznał konsumenta końcowego za centralną postać rynku energii elektrycznej. Nowy model rynku ma sprzyjać budowie rozproszonych źródeł wytwórczych, co może się okazać wyzwaniem dla scentralizowanego systemu elektroenergetycznego w Polsce i będzie oznaczał jego kosztowną przebudowę.

37 Stanowi o tym artykuł 16 ust. 8, Rozporządzenie Parlamentu i Rady (UE) 2019/943, z dnia 5 czerwca 2019 r., w sprawie rynku wewnętrznego energii elektrycznej.

38 L. Bronk, B. Czarnecki, R. Magulski, Elastyczność krajowego systemu elektroenergetycznego. Diagnoza, potencjał, rozwiązania, „Forum Energii” 2019, luty, s. 19. 
Wyraźnie rysuje się trend odchodzenia od wielkoskalowej energetyki, zwłaszcza opartej o konwencjonalne źródła, na rzecz mniejszych źródeł zlokalizowanych blisko odbiorców. W tym kontekście należałoby ponownie przeanalizować potrzebę budowy elektrowni atomowej w Polsce.

Należy z uwagą śledzić planowane zmiany w zakresie szeroko rozumianej polityki energetyczno-klimatycznej Unii Europejskiej. Instytucje unijne pracują nad ogólnounijnym systemem klasyfikacji inwestycji zrównoważonych środowiskowo. Taksonomia zostanie w pełni rozwinięta w aktach delegowanych odnoszących się w pierwszej kolejności do dwóch pierwszych celów (związanych z łagodzeniem zmian klimatu i dostosowaniem się do zmian klimatu) przyjętych przez Komisję do 31 XII 2020 r., a obowiązujących od 1 I 2021 r. Akt delegowany dotyczący pozostałych czterech celów środowiskowych powinien zostać przyjęty przez Komisję także do 31 XII 2020 r., ale obowiązywać będzie dopiero od 1 I $2023 \mathrm{r}$. Wprowadzanie taksonomii jest procesem, który należy pilnie obserwować, a w miarę możliwości kreować i modyfikować. Określi on bowiem rodzaje inwestycji i działalności gospodarczej, która jako zrównoważona środowiskowo będzie mogła być finansowana ze środków unijnych. Uznanie np. energii jądrowej jako działalności niezrównoważonej środowiskowo w sposób znaczący może utrudnić finansowanie budowy polskiej elektrowni jądrowej.

\section{Abstract \\ Marcin Koczan \\ The process of creation the goals of the European Union's energy and climate policy until 2030. Consequences for Poland}

This study analyses the first energy and climate package adopted in 2008 (the socalled „20-20-20" package), setting goals for the European Union and the member states by 2020 . Then describes the process of shaping the goals of the energy and climate policy of the European Union until 2030. The author focuses on the aspects that affect the electricity sector in Poland, boost renewable energy usage, re-form the European energy market and reducing $\mathrm{CO}_{2}$ emissions. The text ends with conclusions and recommendations regarding the impact of the European Union's energy and climate policy on the electricity sector in Poland.

Keywords: European Union, energy and climate policy, polish energy sector, renewable energy sources 


\section{References}

\section{Documents}

Dyrektywa Parlamentu Europejskiego i Rady 2003/87/WE, z dnia 13 października 2003 r., ustanawiająca system handlu przydziałami.

Dyrektywa Parlamentu Europejskiego i Rady 2006/32/WE, z dnia 5 kwietnia 2006 r., w sprawie efektywności końcowego wykorzystania energii i usług energetycznych oraz uchylająca dyrektywę Rady 93/76/EWG.

Dyrektywa Parlamentu Europejskiego i Rady 2009/29/WE, z dnia 23 kwietnia 2009 r. zmieniająca dyrektywę 2003/87/WE w celu usprawnienia i rozszerzenia wspólnotowego systemu handlu uprawnieniami do emisji gazów cieplarnianych.

Decyzja Parlamentu Europejskiego i Rady nr 2009/406/WE z dnia 23 kwietnia 2009 r., w sprawie wysiłków podjętych przez państwa członkowskie, zmierzających do zmniejszenia emisji gazów cieplarnianych w celu realizacji do roku 2020 zobowiązań Wspólnoty dotyczących redukcji emisji gazów cieplarnianych.

Dyrektywa Parlamentu Europejskiego i Rady 2009/31/WE, z dnia 23 kwietnia 2009 r., w sprawie geologicznego składowania dwutlenku węgla oraz zmieniająca dyrektywę Rady 85/337/EWG, Euratom, dyrektywy Parlamentu Europejskiego i Rady 2000/60/WE, 2001/80/WE, 2004/35/WE, 2006/12/WE, 2008/1/ WE i rozporządzenie (WE) nr 1013/2006.

Dyrektywa Parlamentu Europejskiego i Rady 2009/28/WE, z dnia 23 kwietnia 2009 r., w sprawie promowania stosowania energii ze źródeł odnawialnych zmieniająca i w następstwie uchylająca dyrektywy 2001/77/WE oraz 2003/30/ WE.

Informacja NIK o wynikach kontroli: Rozwój sektora odnawialnych źródeł energii, Nr ewid. 171/2017/P/17/020/KGP.

Komunikat Komisji do Parlamentu Europejskiego, Rady, Europejskiego Komitetu Ekonomiczno-Społecznego i Komitetu Regionów, Plan działania prowadzący do przejścia na konkurencyjną gospodarkę niskoemisyjną do 2050 r., Bruksela 9.03.2011, $\mathrm{KOM}(2011) 112$.

Komunikat Komisji, Plan działania prowadzący do przejścia na konkurencyjną gospodarkę niskoemisyjną do 2050 r., Bruksela 9.03.2011, $\operatorname{KOM(2011)~112,~}$ s. 7.

Komunikat Komisji do Parlamentu Europejskiego, Rady, Europejskiego Komitetu Ekonomiczno-Społecznego i Komitetu Regionów, Plan działania w zakresie energii do roku 2050, Bruksela 15.12.2011, KOM(2011) 885.

Komunikat Komisji do Parlamentu Europejskiego, Rady, Europejskiego Komitetu Ekonomiczno-Społecznego i Komitetu Regionów, Ramy polityczne na okres 2020-2030 dotyczące klimatu i energii, COM(2014)15 final. 
Komunikat Komisji do Parlamentu Europejskiego, Rady Europejskiej, Rady, Komitetu Ekonomiczno-społecznego i Komitetu regionów, Europejski Zielony Ład, Bruksela, 11.12.2019, COM(2019) 640 final.

Krajowy plan na rzecz energii i klimatu na lata 2021-2030. Założenia i cele oraz polityki i działania, PROJEKT - w. 3.1 z 04.01.2019, Tekst dostępny na stronie Ministerstwa Aktywów Państwowych https://www.gov.pl/web/aktywa-panstwowe. Raport Zintegrowany 2018, Polska Grupa Energetyczna, https://raportzintegrowany2018.gkpge.pl

Rozporządzenie Parlamentu Europejskiego i Rady (UE) 2019/941, z dnia 5 czerwca 2019 r., w sprawie gotowości na wypadek zagrożeń w sektorze energii elektrycznej i uchylające dyrektywę 2005/89/WE, Dz. Urz. UE z 14.06.2019, L 158. Rozporządzenie Parlamentu Europejskiego i Rady (UE) 2019/942, z dnia 5 czerwca 2019 r., ustanawiające Agencję Unii Europejskiej ds. Współpracy Organów Regulacji Energetyki, Dz. Urz. UE z 14.06.2019, L 158/22.

Rozporządzenie Parlamentu Europejskiego i Rady (UE) 2019/943, z dnia 5 czerwca 2019 r., w sprawie rynku wewnętrznego energii elektrycznej, Dz. Urz. UE, 14.6.2019 L 158/54; Dyrektywa Parlamentu Europejskiego i Rady (UE) 2019/944, z dnia 5 czerwca 2019 r., w sprawie wspólnych zasad rynku wewnętrznego energii elektrycznej oraz zmieniająca dyrektywę 2012/27/U E, Dz. Urz. UE z 14.6.2019, L 158/125.

Ustawa z dnia 27 września 2013 r., o zmianie ustawy Prawo geologiczne i górnicze oraz niektórych innych ustaw, Dz. U. 2013 poz. 1238.

Zielona Księga. Ramy polityki w zakresie klimatu i energii do roku 2030. Bruksela 27.03.2013. $\operatorname{COM(2013)~} 169$ final.

Articles

Bieliszczuk, B., Rozwój odnawialnych źródeł energii - implikacje dla bezpieczeństwa i polityki zagranicznej Polski, „Biuletyn PISM”, nr 56 (1804).

Bronk, L., Czarnecki, B., Magulski, R., Elastyczność krajowego systemu elektroenergetycznego. Diagnoza, potencjał, rozwiązania, „Forum Energii”, february 2019. Jeszke, R., Rosłaniec, M., Pyrka, M., Tobiasz, I., Mzyk, P., „Europejski Zielony Ład” a podniesienie ambicji klimatycznych UE do 2030 roku, „Polish Brief Energy” 2020, nr 1-2.

Oksińska, B., Porażka Polski w rozwoju OZE. Nie osiagniemy celu, https://www. rp.pl/ENERGIA-OZE/301139983-Porazka-Polski-w-rozwoju-OZE-Nieosiagniemy-celu.html.

Schnell, Ch., Wykonanie celu OZE 2020. Analiza stanu obecnego i prognoza, Warszawa 2016.

Sobolewski, M., Pakiet „Czysta energia dla wszystkich Europejczyków” - nowa inicjatywa w dziedzinie unijnej polityki energetycznej, „Studia BAS” 2017, nr 3 (51). 
Marcin Koczan - dr politologii, adiunkt w Zakładzie Badań Wschodnich w Instytucie Studiów Międzynarodowych Uniwersytetu Wrocławskiego.

ORCID: 0000-0002-8039-6820 